\title{
Relationship between Access to Mall and Shopping Motivation of Young Adult Age Group
}

\author{
Tri Widianti Natalia \\ Fakultas Teknik dan Ilmu Komputer \\ Universitas Komputer Indonesia \\ Bandung, Indonesia \\ tri.widianti@email.unikom.ac.id
}

\author{
Hanson Endra Kusuma \\ Sekolah Arsitektur, Perencanaan dan Pengambangan Kebijakan \\ Institut Teknologi Bandung \\ Bandung, Indonesia \\ hekusuma@gmail.com
}

\begin{abstract}
The rise of Shopping Mall development in Bandung causes differences in shopping motivation. The main purpose of visiting Shopping Mall is not only for utilitarian activities but rather hedonic. The differences shopping motivation (Utilitarian and Hedonic) one of them related to Situational Facto, namely access to the mall. The purpose of this study is to identify the relationship between accesses to the mall (Situational Specific) with the Motivation of shopping (Personal Specific) of young adult consumers in Bandung city. Data were collected by questionnaire and analyzed by Anova analysis method, Cluster analysis and Correlation analysis. The results of this study indicate that young age groups of differences in hedonic and utilitarian motivation characteristics towards access to the mall. Hedonic groups have a positive value at the level of ease of access from home to the mall. While Utilitarian groups have a negative value at the level of ease of access from home to the mall, the level of ease of access from office to the mall. Young adult age groups with utilitarian motivation very consider about the access to the mall while visiting the mall. The results of this study can be used by mall developers for shopping mall business strategies.
\end{abstract}

Keywords - Shopping Mall, shopping motivation, access.

\section{INTRODUCTION}

The rise of Shopping Mall in the Bandung City cause differences in shopping motivation. The main purpose of the most people to visit Shopping Mall is for shopping or utilitarian motivation, now it has begun to develop in hedonic activities such as sightseeing. This shopping motivation is one of the personal spesific factors that arise from within a person.

Shopping motivation divided into 2, Utilitarian Motivation and Hedonic Motivation [1]. Utilitarian motivation visits the mall with an economic orientation to meet their needs. While Hedonic motivation visits the mall with pleasure orientation, looking for entertainment, and social interaction $[2,3]$

Shopping motivation is internal factor and become one of the factors that influence consumer behavior in shopping, this shopping motivation is a factor that comes from within each consumer personally (internal factors) or commonly called personal - specific. Therefore, knowing the shopping motivation of mall visitors is very important to know what goals and activities are carried out by Mall visitors. Characteristic construction of shopping motivation are divided into two, Hedonic Motivation and Utilitarian Motivation [2]

Hedonic motivation has a mission to not have to get goods (buy) when visiting a shopping place [3]. Consumer with hedonic motivation, in visiting shopping mall have orientation for entertainment activities, social activities, and other pleasure activities. These following are the Hedonic Motivation Characteristics Construction : Gratification Shopping [2,4] Adventure Shopping [2] Social Shopping [2,5], Explorations Shopping [2,4], Role Shopping [2]. Utilitarian motivation has a mission to get goods (buy) when visiting a shopping place. Consumer with utilitarian motivation, in visiting shopping mall have an orientation to meet economic needs. These following are the Utilitarian Motivation Characteristics Construction : Efficency Shopping [2, 5], Achievement Shopping [2]

Difference in shopping motivation (Utilitarian and Hedonic), one of them is closely related to the access factor to the mall which is a specific situational factor. Access convenience and the distance between house and workplace towards the Shopping Mall will affect shopping enjoyment with Utilitarian and Hedonic shopping motivation [2, 9]. Builders generation group and utilitarian motivation are very concerned about the location convenience such as the nearest mall facilities, access and mall location that is convenient and easy from house, workplace and street [1].

To complement previous research on the relationship of access to mall and shopping motivation, make this research necessary to be done. However, the scope of the study that will be examined in this research is the adult age group which is the age group that most often visits the Shopping Mall. The purpose of this research was to identify the relationship between access to the mall (Situational Specific) with the Utilitarian and Hedonic shopping motivation (Personal Specific) of adult age group consumer in Bandung City. 


\section{METHOD}

\section{A. Research Methods}

This research used quantitative methods [6] which is correlational wich focused on the relationship of access variables to the mall with utilitarian and hedonic shopping motivation.

\section{B. Data Collection Methods}

Data collection was carried out through surveys using a closed questionnaire. All respondents are young adult age groups between 17-40 years. The total number of respondents is 300 respondents from 30 districts in Bandung City, in each district represented by 10 respondents (quota sampling). Respondent in each region were selected by convenience sampling [7].

\section{Data Analysis Methods}

In the questionnaire, identification of access to the mall and characteristics of hedonic and utilitarian motivation were carried out using a closed questionnaire with 1 point (strongly disagree) to point 6 (strongly agree) Likert scale. Cluster analysis was carried out to see the close group relationship of the hedonic and utilitarian motivation, with the travel time to the mall. Anova analysis was conducted to see the different characteristics of access to the mall based on hedonic and utilitarian shopping motivation

\section{RESULT}

Distribution analysis is conducted on sociodemographic data to understand the background of young adult age consumer and to facilitate interpretation of the results of subsequent analyzes.

\section{A. Sociodemographic Data of Respondents}

Figure 1 shows the results of the distribution analysis of sociodemographic data of respondents who are young adult age groups.

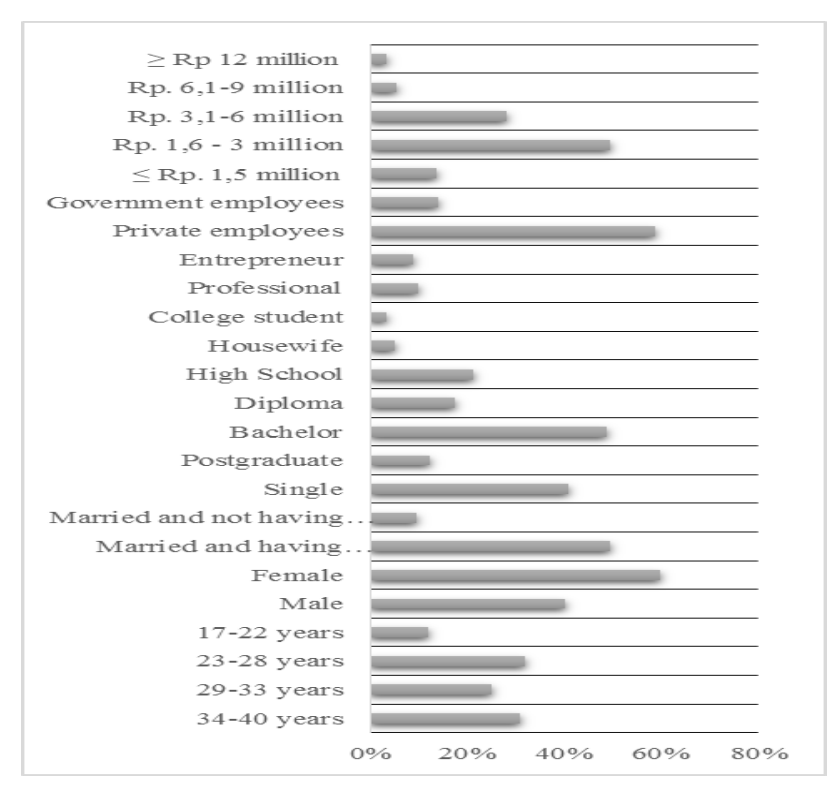

Fig. 1. Sociodemographic Data of Respondents
Respondents are young adult age groups with ages ranging from 17 to 40 years [8]. Respondents aged 23-28 years are the age group of respondents who dominate, with a percentage of $32 \%$. Respondents with ages 34-40 years were $31 \%$, respondents with ages $29-33$ years were $25 \%$, respondents with ages 17-22 years were $12 \%$. Most respondents are female with a percentage of $60 \%$, while male are $40 \%$.

Most respondents are married and have children with a percentage of $49 \%$, married do not have children by $10 \%$, and those who are single are $41 \%$. The last education of respondents was dominated by scholars, with a percentage of $49 \%$. This is because this age range is an age as an undergraduate student. While $18 \%$ are respondents with diploma education, $21 \%$ high school, and $12 \%$ postgraduate.

Most of the work of respondents is private employees, with a percentage of $59 \%$, Government employees $14 \%$, professionals 10\%, Entrepreneurs 9\%, Housewife 5\% and students $3 \%$. Some respondents have an average income of 1.6-3 million with a percentage of 49\%, 3.1-6 million $28 \%$, less than 1.5 million $14 \%, 6-9$ million $5 \%$, and above 12 million $3 \%$.

The most dominant age groups are between 23-28 years and 34-40 years, mostly women, with married and having children status, the last education dominated by scholars, and income around 1.5-3 million, or 1-2 times Regional Minimum Wage and work as private workers.

\section{B. Hedonic and utilitarian motivation characteristics of access to the Mall}

Figure 2 shows the results of Anova analysis of differences in hedonic and utilitarian motivation characteristics towards access to the mall.

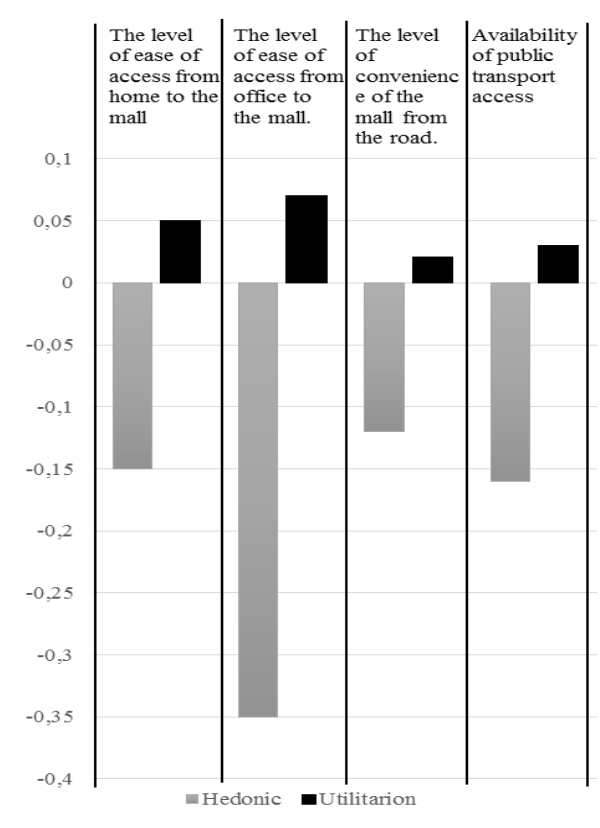

Fig. 2. The difference between hedonic and utilitarian motivation characteristics of access to the Mall 
Hedonic groups have a positive value towards the level of ease of access from home to the mall, the level of ease of access from office to the mall, the level of convenience of the mall from the road and availability of public transport access. The Hedonic motivation group will not be affected by access factors when visiting the mall.

While Utilitarian groups have a negative value towards the level of ease of access from home to the mall, the level of ease of access from office to the mall, the level of convenience of the mall from the road and availability of public transport access. The Hedonic motivation group will not be affected by access factors when visiting the mall. Consumer with utilitarian motivation is very concerned about the level of ease of access from the office when heading to the mall.

\section{The close relationship between shopping motivation and travel time}

Figure 3 shows The close relationship between shopping motivation and travel time from the Office to the Mall.

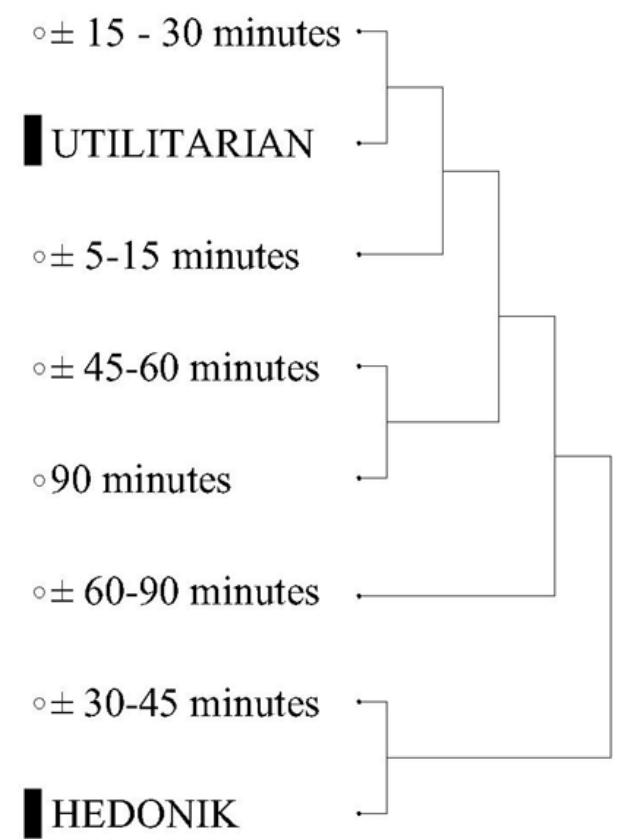

Fig.3. The close relationship between shopping motivation and travel time from the Office to the Mall

The utilitarian motivation will visit a mall that has a travel time 5-30 minutes and 15-30 minutes from the workplace. While the hedonic motivation group will visit the mall that has a travel time 30-90 minutes and 60-90 minutes from the workplace.

\section{DISCUSSION}

Figure 2 shows the results of Anova analysis of differences in hedonic and utilitarian motivation characteristics towards access to the mall. Consumer with utilitarian motivation is very concerned about the level of ease of access from the office when heading to the mall. This is because most respondents are productive age who are still working.

Utilitarian motivation is very concerned about access from the office, because most of these motivational groups go to the mall to get items that have been planned in a short time, fast and only have an economic orientation. So, the distance and close access, easy and fast become their main consideration for visiting the mall. The results of this reseach support the results of the reseach [5] regarding utilitarian motivation groups that consider the convenience of access from home and workplace when heading to the Shopping mall.

While the Hedonic motivation group will not be affected by access factors when visiting the mall. This is because the main purpose of this motivation group to visit the mall is for pleasure activity, sightseeing, entertainment and social interaction with friends or family. So, easy or difficult access are not a factor in their consideration for visiting the mall.

Figure 3 shows that utilitarian motivation will visit a mall that has a travel time 5-30 minutes from the workplace. This means the utilitarian motivation group will visit the mall that is close to the workplace, to get their needs in a short time and fast after they return from work. The results of this research support the research [4] which reveals that the Utilitarian Motivation group will visit a Mall that has easy distance and access and close to where they live and work.

While the hedonic motivation group will visit the mall that has a travel time 30-90 minutes from the workplace. This is because their goal of visiting the mall is for pleasure activity, sightseeing, social interaction with friends to eliminate boredom, fatigue and stress after work [10]. So they will look for a Mall that is far away from their workplace. The results of this research support the results of previous research which revealed that the hedonic motivation group did not consider access to the mall [1].

\section{CONCLUSION}

Young adult age groups with utilitarian motivation very consider about the access to the mall while visiting the mall. Easy access from the workplace with a travel time 5 - 30 minutes is the main consideration of the utilitarian motivation group. This is because the main purpose of the utilitarian motivation group when visiting the mall is to get their needs in a short time and fast after they return from work. While the hedonic motivation group does not consider access to the mall. Easy access from home, office, main street, and access to public transportation with a travel time 30-90 minutes from the office is not a problem for them to visit the mall. This is because the main purpose of hedonic motivation groups to visit the mall is for pleasure activities. 


\section{REFERENCES}

[1] J. Vanessa, S. Leslie, B. Aquia, "Mall attributes and shopping value: Differences by gender and generational cohort," Journal of Retailing and Consumer Services 18, pp. 1-9, 2011

[2] K. Hye-Shin, "Using Hedonic and Utilitarian Shopping Motivations to Profile Inner City Consumers," Journal of Shopping Center Research, 13, Number 1, pp 57-79, 2006.

[3] M.P.E. Yasin, "Motivasi Pengunjung Ke Shopping mall Pada Studi Kasus Bandung Indah Plasa," Temu Ilmiah IPLBI 2012, pp 5-8, 2012.

[4] R. K. Tiwari, A. Anish, "Understanding The Consumer Behavior Towards Shopping Malls In Raipur City," International Journal of Management \& Strategy, vol.1, 2010.

[5] W. Yue-Teng, S. Osman, A. Jamaluddin, B. Yin-Fah, "Shopping motives, store attributes and shopping enjoyment among Malaysian youth," Journal of Retailing and Consumer Services, 19, pp 24024, 2012.

[6] J.W. Creswell, Research Design: Qualitative, Quantitative, and Mixed Methods Approaches. California: Sage Publications, Inc, 2008.

[7] K. Ranjit, Research Methodology, New Delhi: Sage Publications India Pvt Ltd, 2005

[8] Grysole. Amelie, Emotional and Social Development in Early Adulthood, Haiti, 2009

[9] Allard. Thomas, Babin. Jbarry, "When income matters:

Customers evaluation of Shopping malls' hedonic and utilitarian orientations", Journal of Retailing and Consumer Services Vol.16, pp 40-49, 2009

[10] Gilboa. Shaked, Yavetz, "Four generations of Mall visitors in Israel: A study of Mall activities, visiting patterns, and products purchased", Journal of Retailing and Consumer Services Vol. 17, pp 501-511, 2010 